\title{
Reversible and irreversible deactivation of Cu-CHA NH3-SCR catalysts by SO2 and SO3
}

Hammershøi, Peter S.; Jangjou, Yasser; Epling, William S.; Jensen, Anker D.; Janssens, Ton V.W.

\section{Published in:}

Applied Catalysis B: Environmental

Link to article, DOI:

10.1016/j.apcatb.2017.12.018

Publication date:

2018

Document Version

Peer reviewed version

Link back to DTU Orbit

Citation $(A P A)$ :

Hammershøi, P. S., Jangjou, Y., Epling, W. S., Jensen, A. D., \& Janssens, T. V. W. (2018). Reversible and irreversible deactivation of $\mathrm{Cu}-\mathrm{CHA} \mathrm{NH}$ - $\mathrm{SCR}$ catalysts by $\mathrm{SO}_{2}$ and $\mathrm{SO}_{3}$. Applied Catalysis B: Environmental,
226, 38-45. https://doi.org/10.1016/j.apeatb.2017.12.018

\section{General rights}

Copyright and moral rights for the publications made accessible in the public portal are retained by the authors and/or other copyright owners and it is a condition of accessing publications that users recognise and abide by the legal requirements associated with these rights.

- Users may download and print one copy of any publication from the public portal for the purpose of private study or research.

- You may not further distribute the material or use it for any profit-making activity or commercial gain

- You may freely distribute the URL identifying the publication in the public portal 


\section{Accepted Manuscript}

Title: Reversible and irreversible deactivation of $\mathrm{Cu}-\mathrm{CHA}$

$\mathrm{NH}_{3}$-SCR catalysts by $\mathrm{SO}^{2}$ and $\mathrm{SO}_{3}$

Authors: Peter S. Hammershøi, Yasser Jangjou, William S.

Epling, Anker D. Jensen, Ton V.W. Janssens

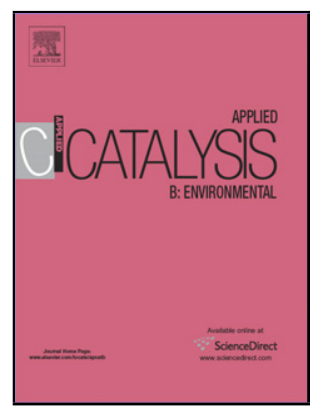

PII:

S0926-3373(17)31167-0

DOI:

https://doi.org/10.1016/j.apcatb.2017.12.018

Reference:

APCATB 16253

To appear in:

Applied Catalysis B: Environmental

Received date:

7-9-2017

Revised date:

5-12-2017

Accepted date:

8-12-2017

Please cite this article as: Peter S.Hammershøi, Yasser Jangjou, William S.Epling, Anker D.Jensen, Ton V.W.Janssens, Reversible and irreversible deactivation of $\mathrm{Cu}-\mathrm{CHA}$ NH3-SCR catalysts by $\mathrm{SO} 2$ and $\mathrm{SO} 3$, Applied Catalysis B, Environmental https://doi.org/10.1016/j.apcatb.2017.12.018

This is a PDF file of an unedited manuscript that has been accepted for publication. As a service to our customers we are providing this early version of the manuscript. The manuscript will undergo copyediting, typesetting, and review of the resulting proof before it is published in its final form. Please note that during the production process errors may be discovered which could affect the content, and all legal disclaimers that apply to the journal pertain. 


\section{Reversible and irreversible deactivation of $\mathrm{Cu}-\mathrm{CHA} \mathrm{NH} \mathrm{N}_{3}-\mathrm{SCR}$ catalysts by $\mathrm{SO}_{2}$ and $\mathrm{SO}_{3}$}

Peter S. Hammershøia ${ }^{\mathrm{a}, \mathrm{b}, 1}$, Yasser Jangjou ${ }^{\mathrm{c}, \mathrm{d}}$, William S. Epling ${ }^{\mathrm{c}, \mathrm{d}}$, Anker D. Jensen $^{\mathrm{b}}$, Ton V.W. Janssens ${ }^{\mathrm{a}, *, 1}$

aHaldor Topsøe A/S, Haldor Topsøe's Allé 1, 2800 Kgs. Lyngby, Denmark ${ }^{\mathrm{b}}$ Department of Chemical and Biochemical Engineering, Technical University of Denmark, Søltofts Plads B229, $2800 \quad$ Kgs. Lyngby, Denmark ${ }^{\mathrm{c}}$ Department of Chemical and Biomolecular Engineering, University of Houston, 4800 Calhoun Rd., Houston, TX 77204-4004, United States 'Department of Chemical Engineering, University of Virginia, 102 Engineers' Way, Charlottesville, VA 22904-4741

${ }^{1}$ Present address: Umicore Denmark ApS, Nøjsomhedsvej 20, DK-2800 Kgs. Lyngby, Denmark.

*Corresponding author. Phone: +45 227546 22, e-mail address: tonv.w.janssens@eu.umicore.com

Graphical abstract

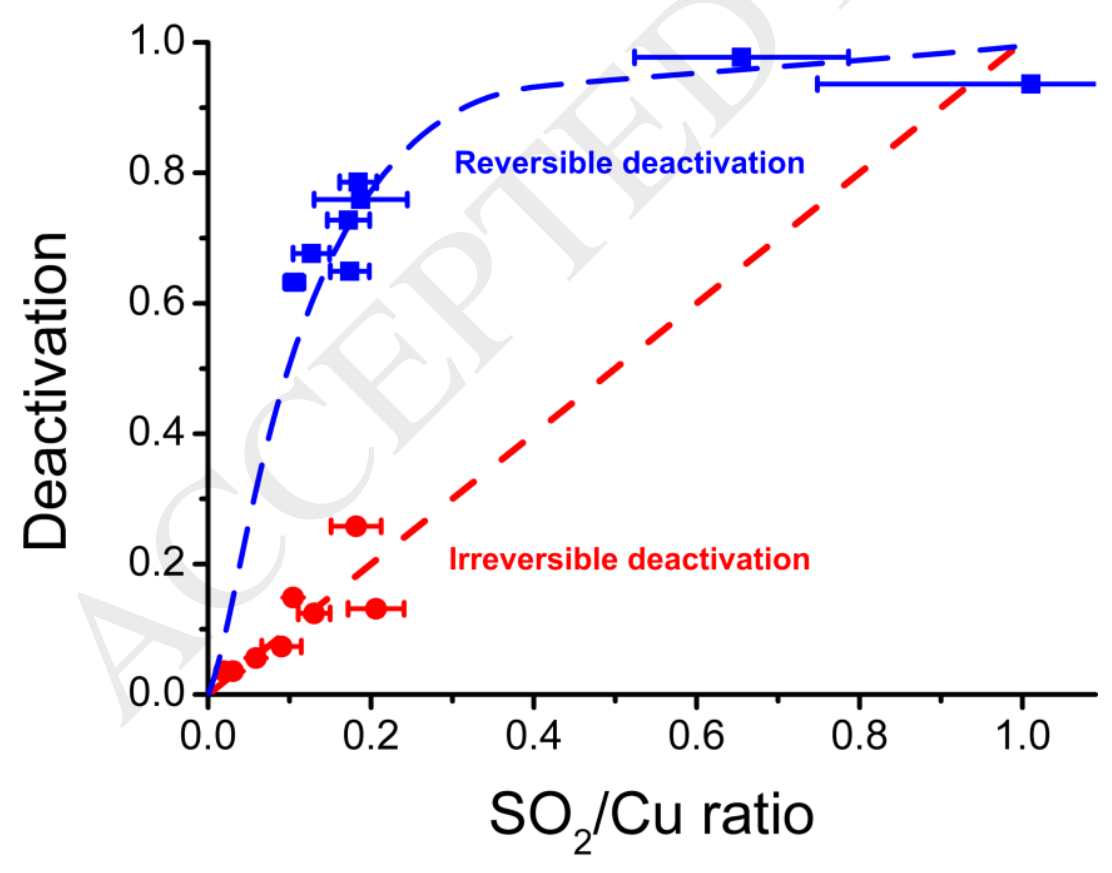




\section{Highlights}

- $\mathrm{SO}_{\mathrm{x}}$-poisoned $\mathrm{Cu}$-CHA is partially regenerated by heating to $550{ }^{\circ} \mathrm{C}$.

- The irreversible part of deactivation scales with $\mathrm{S} / \mathrm{Cu}$ ratio; reversible deactivation is higher than expected from $\mathrm{S} / \mathrm{Cu}$ ratios.

- Presence of $\mathrm{SO}_{3}$ affects deactivation at $200{ }^{\circ} \mathrm{C}$, but not at $550{ }^{\circ} \mathrm{C}$.

- Presence of $\mathrm{H}_{2} \mathrm{O}$ and $\mathrm{SO}_{\mathrm{x}}$ exposure at low temperature lead to higher irreversible deactivation

\section{Abstract}

Sulfur oxides are a common source for the deactivation of $\mathrm{Cu}$-exchanged $\mathrm{CHA}$ zeolite based catalysts used for $\mathrm{NO}_{\mathrm{x}}$ reduction in diesel exhausts by selective catalytic reduction with $\mathrm{NH}_{3}\left(\mathrm{NH}_{3}-\mathrm{SCR}\right)$. Since water and possible formation of $\mathrm{SO}_{3}$ affect the deactivation of $\mathrm{Cu}-\mathrm{CHA}$ catalysts, the deactivation in the presence of $\mathrm{SO}_{2}$ or a mixture of $\mathrm{SO}_{2}$ and $\mathrm{SO}_{3}$ was studied by measuring the SCR activity in wet and dry gas at 200 and $550{ }^{\circ} \mathrm{C}$. The estimated S-content in the catalysts before and after $4 \mathrm{~h}$ regeneration at $550{ }^{\circ} \mathrm{C}$ in $\mathrm{NO}, \mathrm{NH}_{3}, \mathrm{O}_{2}$ and $\mathrm{H}_{2} \mathrm{O}$ was related to the deactivation. The deactivation can be divided into two parts: a reversible deactivation that is restored by the regeneration treatment, and an irreversible part. The irreversible deactivation does not affect the activation energy for $\mathrm{NH}_{3}-\mathrm{SCR}$ and display a 1:1 correlation with the S-content, consistent with deactivation by $\mathrm{Cu}$-sulfate formation. The reversible deactivation results in a lower activation energy and a deactivation that is larger than expected from the S-content. The presence of $\mathrm{SO}_{3}$ at $200{ }^{\circ} \mathrm{C}$ leads to higher reversible and irreversible deactivation, but has no significant impact at $550{ }^{\circ} \mathrm{C}$. Furthermore, the irreversible deactivation is always higher when exposed at $200{ }^{\circ} \mathrm{C}$ than at $550{ }^{\circ} \mathrm{C}$, and in wet conditions, compared to a dry feed. The deactivation is predominantly reversible, making regeneration at $550{ }^{\circ} \mathrm{C}$ a realistic approach to handle S-poisoning in exhaust systems.

Keywords NH3-SCR, Cu-CHA, deactivation, sulfur oxides, regeneration 


\section{Introduction}

Combustion of diesel fuel in automotive engines produces $\mathrm{NO}_{\mathrm{x}}\left(\mathrm{NO}\right.$ and $\left.\mathrm{NO}_{2}\right)$. Due to the environmentally negative impact of $\mathrm{NO}_{\mathrm{x}}$, emissions of these compounds are subject to strict regulations, which requires $\mathrm{NO}_{\mathrm{x}}$ reduction from the exhaust gas. The current technology for the removal of $\mathrm{NO}_{\mathrm{x}}$ is selective catalytic reduction $(\mathrm{SCR})$ of $\mathrm{NO}_{\mathrm{x}}$ with $\mathrm{NH}_{3}$. Apart from an $\mathrm{NH}_{3}-\mathrm{SCR}$ catalyst, a complete diesel exhaust after-treatment system also contains a diesel oxidation catalyst to oxidize $\mathrm{CO}$ and unburnt fuel, a particle filter to remove soot, and an ammonia slip catalyst to remove the ammonia not used in the upstream $\mathrm{NH}_{3}-\mathrm{SCR}$ reaction.

The best known $\mathrm{NH}_{3}$-SCR catalysts are based on $\mathrm{V}_{2} \mathrm{O}_{5}$, or $\mathrm{Cu}$ - or Fe-zeolites. Compared to $\mathrm{V}_{2} \mathrm{O}_{5}$-based catalyst systems, Cu-zeolites generally work well in a broader temperature region $\left(\sim 150-500{ }^{\circ} \mathrm{C}\right)[1]$. In particular, the better low temperature activity for $\mathrm{Cu}$-zeolites is of interest for cold-start conditions. Combined with the good hydrothermal stability of small-pore zeolites, these traits have led to commercialization of $\mathrm{Cu}$-zeolites in diesel engine exhaust systems, and $\mathrm{Cu}-\mathrm{CHA}$ is the current stateof-the-art Cu-zeolite catalyst for diesel emission control.

Another important requirement for $\mathrm{NH}_{3}$-SCR catalysts is low susceptibility to $\mathrm{SO}_{2}$-poisoning. Diesel fuels contain a small amount of sulfur, and even ultra-low sulfur fuel will result in $\mathrm{SO}_{2}$ in the exhaust gas. The performance of $\mathrm{NH}_{3}-\mathrm{SCR}$ catalysts, however, can be very sensitive to the presence of $\mathrm{SO}_{2}$, even at low concentrations, as in ultra-low sulfur diesel [2]. It is therefore important to know the effect of $\mathrm{SO}_{2}$ on the performance of an $\mathrm{NH}_{3}-\mathrm{SCR}$ catalysts.

Unfortunately, Cu-zeolite catalysts deactivate more in the presence of $\mathrm{SO}_{2}$ in the exhaust gas, while Fe-zeolites are less affected by $\mathrm{SO}_{2}$ and $\mathrm{V}_{2} \mathrm{O}_{5}$ is not affected $[1,3,4]$. Consequently, to be able to exploit the potentially better performance of $\mathrm{Cu}$-zeolite catalysts in an exhaust after-treatment system, it is important to understand how the presence of $\mathrm{SO}_{2}$ influences the performance of these catalysts. 
Furthermore, it is also important to know to what degree the deactivation of $\mathrm{Cu}$-zeolites induced by $\mathrm{SO}_{2}$ is reversible versus irreversible.

The current understanding of $\mathrm{Cu}$-zeolite catalyst deactivation by $\mathrm{SO}_{2}$, and $\mathrm{Cu}-\mathrm{CHA}$ in particular, is that it originates from $\mathrm{SO}_{2}$ interaction with the $\mathrm{Cu}$-sites. This can simply be adsorption of $\mathrm{SO}_{2}$ or could involve a chemical reaction between the $\mathrm{SO}_{2}$ and $\mathrm{Cu}$-sites [2,5-13]. X-ray photoemission and X-ray absorption spectroscopy indicate that the $\mathrm{Cu}$ in the ion-exchange positions reacts to form a $\mathrm{CuSO}_{4}$-like species [2]. The formation of sulfates suggests that some oxidation of $\mathrm{SO}_{2}$ to $\mathrm{SO}_{3}$ takes place. In an after-treatment system, oxidation of $\mathrm{SO}_{2}$ to $\mathrm{SO}_{3}$ can occur on the diesel oxidation catalyst [2,11], and on the $\mathrm{NH}_{3}$-SCR catalyst [5]. A higher sulfur uptake and stronger deactivation has been observed in the presence of $\mathrm{SO}_{3}$ in the feed gas $[2,11]$. Therefore, a better understanding of the effect of $\mathrm{SO}_{3}$ on the performance of $\mathrm{NH}_{3}-\mathrm{SCR}$ catalysts is needed.

Another mechanism for deactivation of $\mathrm{NH}_{3}-\mathrm{SCR}$ catalysts is the formation of ammonium sulfate on the catalyst, which restricts access to the active sites. The presence of $\mathrm{SO}_{2}$ or $\mathrm{SO}_{3}$ in a standard, $\mathrm{NH}_{3}$ containing SCR-gas causes formation of ammonium sulfate, which is a solid below $300{ }^{\circ} \mathrm{C}$, and therefore, deactivation by ammonium sulfate only occurs in the low-temperature range. Ammonium sulfate can be removed by heating the catalyst to above $350{ }^{\circ} \mathrm{C}$, which means that regeneration from this type of deactivation is possible in an exhaust system $[5,9,10]$.

An $\mathrm{NH}_{3}-\mathrm{SCR}$ catalyst in a diesel exhaust treatment system is typically operated between $200-550{ }^{\circ} \mathrm{C}$, and in the presence of $5-10 \%$ water vapor. The effect of temperature on catalyst deactivation by $\mathrm{SO}_{\mathrm{x}}$ depends on the presence of $\mathrm{SO}_{3}[2,11]$. With $\mathrm{SO}_{2}$ only, the deactivation is more severe at $200{ }^{\circ} \mathrm{C}$ than at $400{ }^{\circ} \mathrm{C}$, while the opposite trend is observed in the presence of $\mathrm{SO}_{3}[2,11]$.

Water also interacts with the $\mathrm{Cu}$ ions, changing the environment of and around the active sites in a $\mathrm{Cu}$ $\mathrm{CHA}$ catalyst. Water vapor is known to partially hydrolyze the $\mathrm{Cu}$-sites at temperatures below $250{ }^{\circ} \mathrm{C}$ 
[14], affecting the performance for $\mathrm{NH}_{3}-\mathrm{SCR}$. In a similar way, reactions between different $\mathrm{Cu}$-sites with sulfur oxides can be affected by water as well $[8,15]$. From a mechanistic point of view, the impact of water vapor on the deactivation by $\mathrm{SO}_{2}$ and $\mathrm{SO}_{3}$ should be understood, with the additional consideration that $\mathrm{SO}_{3}$ and $\mathrm{H}_{2} \mathrm{O}$ combine and form sulfuric acid below $400{ }^{\circ} \mathrm{C}$ [11].

In practice, there are essentially two ways to deal with the presence of $\mathrm{SO}_{\mathrm{x}}$ in an exhaust gas. The first one is to design the $\mathrm{Cu}-\mathrm{CHA} \mathrm{SCR}$ catalysts in such a way that the amounts of $\mathrm{SO}_{2}$ and $\mathrm{SO}_{3}$ passing through the system during its lifetime can be accommodated in the system. Alternatively, periodic regeneration strategies must be designed that restore at least a part of the catalytic activity. It is therefore important to know how the presence of $\mathrm{SO}_{2}$ and $\mathrm{SO}_{3}$ in the exhaust gas stream affects the performance of $\mathrm{Cu}-\mathrm{CHA}$ catalyst and if regeneration of a $\mathrm{Cu}-\mathrm{CHA}$ catalyst is possible. In this article, we focus on the effect of the temperature and $\mathrm{H}_{2} \mathrm{O}$ and $\mathrm{SO}_{3}$ on the $\mathrm{SO}_{\mathrm{x}}$-induced deactivation of a monolithic $\mathrm{Cu}$ CHA catalyst for $\mathrm{NH}_{3}-\mathrm{SCR}$. The stability of species formed was studied by comparing the activities of a deactivated catalyst with that after heating to $550{ }^{\circ} \mathrm{C}$, which is a temperature that can be reached in an exhaust system.

\section{Experimental}

\subsection{Preparation of the catalysts}

In this study we used both a $\mathrm{Cu}-\mathrm{CHA}$ powder catalyst and a monolithic $\mathrm{Cu}-\mathrm{CHA}$ catalyst. For the powdered catalyst, $\mathrm{Cu}$ was introduced into the $\mathrm{H}$-CHA zeolite by ion-exchange for $24 \mathrm{~h}$ with an aqueous solution of $\mathrm{Cu}\left(\mathrm{CH}_{3} \mathrm{COO}\right)_{2}(5 \mathrm{mmol} / \mathrm{kg})$ at $20{ }^{\circ} \mathrm{C}$, using $20 \mathrm{~g} \mathrm{H}-\mathrm{CHA}$ zeolite powder in $5 \mathrm{~kg}$ solution. After ion-exchange the $\mathrm{Cu}-\mathrm{CHA}$ was filtered and washed with approx. $20 \mathrm{~L}$ MilliQ water, which resulted in a colorless filtrate. The $\mathrm{Cu}-\mathrm{CHA}$ powder was then dried overnight at $95^{\circ} \mathrm{C}$, and calcined at $550{ }^{\circ} \mathrm{C}$ for $3 \mathrm{~h}$. The $\mathrm{Si} / \mathrm{Al}$ ratio was 14.7 and the $\mathrm{Cu} / \mathrm{Al}$ ratio was 0.5 , corresponding to a Cu-loading of $2.8 \mathrm{wt} \%$, as determined by ICP-OES. 
The monolithic $\mathrm{Cu}-\mathrm{CHA}$ catalyst was prepared by washcoating a cordierite monolith with a slurry of $\mathrm{H}_{2} \mathrm{O}$, xanthan gum, colloidal silica and $\mathrm{Cu}-\mathrm{CHA}$ powder. The $\mathrm{Cu}-\mathrm{CHA}$ powder was prepared by impregnating $1 \mathrm{~kg}$ of $\mathrm{H}-\mathrm{CHA}$ powder $(\mathrm{Si} / \mathrm{Al}=16.6)$ with $\mathrm{Cu}$ in $1 \mathrm{~kg}$ of an aqueous solution of 0.39 $\mathrm{mmol} / \mathrm{g} \mathrm{Cu}\left(\mathrm{NO}_{3}\right)_{2} \cdot 3 \mathrm{H}_{2} \mathrm{O}$ in a rotary evaporator for $4 \mathrm{~h}$ at $95{ }^{\circ} \mathrm{C}$. The $\mathrm{Cu}$-loading of the powder was 2.5 $\mathrm{wt} \%$, based on the amount of $\mathrm{Cu}$ added for the impregnation. After impregnation, the powder was calcined at $550{ }^{\circ} \mathrm{C}$ for $3 \mathrm{~h}$. A cordierite monolith $(\mathrm{D} \times \mathrm{L}=25.4 \times 10.2 \mathrm{~cm}, 300 \mathrm{cpsi}, 0.005 \mathrm{~mm}$ wall thickness) was washcoated with the $\mathrm{Cu}-\mathrm{CHA}$ slurry to a washcoat-loading of $151 \mathrm{~g} / \mathrm{L}$. The $\mathrm{Cu}-$ $\mathrm{CHA} /$ cordierite monolith was dried at $100{ }^{\circ} \mathrm{C}$, and calcined at $550{ }^{\circ} \mathrm{C}$ for $3 \mathrm{~h}$.

\subsection{Catalytic test on powder}

The $\mathrm{NH}_{3}$-SCR activity measurements on the $\mathrm{Cu}-\mathrm{CHA}$ powder were carried out in a fixed-bed quartz reactor with a $2 \mathrm{~mm}$ inner diameter, using $5.0 \mathrm{mg}$ catalyst (150-300 $\mu \mathrm{m}$ sieve fraction) on a dry matter basis. The SCR feed gas composition was 500 ppmv NO, 530 ppmv $\mathrm{NH}_{3}, 10 \% \mathrm{O}_{2}, 5 \% \mathrm{H}_{2} \mathrm{O}$ balanced by $\mathrm{N}_{2}$, which we hereafter refer to as "SCR-gas". The total flow rate used in the measurements was $0.225 \mathrm{NL} / \mathrm{min}\left(10 \mathrm{mmol} / \mathrm{min}\right.$, standard conditions: $\left.\mathrm{T}=0{ }^{\circ} \mathrm{C}, \mathrm{P}=1 \mathrm{~atm}\right)$. The outlet gas was analyzed by a Gasmet CX4000 FTIR analyzer.

The Cu-CHA powder exposure to $\mathrm{SO}_{2}$ was either done in situ in the reactor at $550{ }^{\circ} \mathrm{C}$ for $1 \mathrm{~h}$ with 40 ppmv $\mathrm{SO}_{2}, 10 \% \mathrm{O}_{2}, 5 \% \mathrm{H}_{2} \mathrm{O}$ balanced by $\mathrm{N}_{2}$ with a total flow rate of $0.2 \mathrm{NL} / \mathrm{min}(9 \mathrm{mmol} / \mathrm{min})$, or ex situ in a tube furnace at $550{ }^{\circ} \mathrm{C}$ for $16 \mathrm{~h}$ with $100 \mathrm{ppmv} \mathrm{SO}_{2}, 16 \% \mathrm{O}_{2}$ balanced by $\mathrm{N}_{2}$ with a total flow rate of $0.2 \mathrm{NL} / \mathrm{min}$. Regeneration was always carried out in situ in the reactor at $550{ }^{\circ} \mathrm{C}$ with an SCR-gas flow of $0.225 \mathrm{NL} / \mathrm{min} .550^{\circ} \mathrm{C}$ was chosen, as this is a typical temperature for regeneration of diesel after-treatment systems operating with passive filter regeneration.

\subsection{Catalytic test on monoliths}


With the purpose of studying the impact of temperature and $\mathrm{H}_{2} \mathrm{O}$ and $\mathrm{SO}_{3}$ gas components on $\mathrm{Cu}$ $\mathrm{CHA}$ /cordierite monolith catalyst deactivation by $\mathrm{SO}_{2}$, steady-state $\mathrm{NO}_{\mathrm{x}}$ conversions were measured before and after $\mathrm{SO}_{\mathrm{x}}$ exposure, and after regeneration at $550{ }^{\circ} \mathrm{C}$ in a laboratory flow reactor system with a horizontal quartz reactor with an inner diameter of $25.4 \mathrm{~mm}$. Upstream and downstream tubing inside surfaces were coated with SilcoNert to minimize adsorption of $\mathrm{SO}_{\mathrm{x}}\left(\right.$ and $\left.\mathrm{NH}_{3}\right)$. Monolith samples of approx. $20 \times 27 \mathrm{~mm}$ were cut out from the larger prepared sample (sample masses were between 4.5$5 \mathrm{~g})$. The reactor temperature was measured at the inlet, inside, and at the outlet of the monolith samples by thermocouples placed in the radial center of the reactor/sample. The steady-state $\mathrm{NO}_{\mathrm{x}}$ conversions were measured at various temperatures $\left(130-250{ }^{\circ} \mathrm{C}\right)$, at a flow of $8.0 \mathrm{NL} / \mathrm{min}(357 \mathrm{mmol} / \mathrm{min})$. The SCR feed gas composition was 500 ppmv NO, 530 ppmv $\mathrm{NH}_{3}, 10 \% \mathrm{O}_{2}, 5 \% \mathrm{H}_{2} \mathrm{O}$ balanced by $\mathrm{N}_{2}$. The outlet gas was analyzed using a MKS MultiGas 2030 FTIR. $\mathrm{SO}_{\mathrm{x}}$ exposure was always $3 \mathrm{~h}$ in $10 \% \mathrm{O}_{2}$ with 100 ppmv $\mathrm{SO}_{x}$ balanced by $\mathrm{N}_{2}$ with a total flow rate of $8.0 \mathrm{NL} / \mathrm{min}$. The variations in the $\mathrm{SO}_{\mathrm{x}}$ exposure conditions and the assigned sample names, are listed in Table 1 . The $\mathrm{SO}_{3}$ for the $\mathrm{SO}_{\mathrm{x}}$ exposures, was produced in an upstream reactor by oxidizing $\mathrm{SO}_{2}$ over a $\mathrm{Pt} / \mathrm{Al}_{2} \mathrm{O}_{3}$ monolith catalyst. The temperature of the upstream reactor was adjusted to reach a steady-state conversion of $\mathrm{SO}_{2}$ of 30 $\%$, which was added to the main feed prior to the inlet of the quartz reactor containing the $\mathrm{Cu}$ $\mathrm{CHA} /$ cordierite catalyst. Regeneration was carried out in the SCR feed gas at $550{ }^{\circ} \mathrm{C}$, heating at 10 ${ }^{\circ} \mathrm{C} / \mathrm{min}$, for $4 \mathrm{~h}$. In order to check if there were S-species remaining on the samples after regeneration, temperature-programmed desorption (TPD) to $900{ }^{\circ} \mathrm{C}$ was carried out after the final $\mathrm{NO}_{\mathrm{x}}$ conversion measurement that followed the regeneration. The $\mathrm{SO}_{2}$-TPD was carried out in $\mathrm{N}_{2}$ at a flow rate of 8.0 $\mathrm{NL} / \mathrm{min}$, and with a temperature ramp at $10{ }^{\circ} \mathrm{C} / \mathrm{min}$. The concentrations of $\mathrm{H}_{2} \mathrm{O}, \mathrm{NO}, \mathrm{NO}_{2}, \mathrm{NH}_{3}, \mathrm{SO}_{2}$, $\mathrm{SO}_{3}$ and $\mathrm{H}_{2} \mathrm{SO}_{4}$ were monitored during regenerations and TPD measurements.

\subsection{Evaluation of activity and deactivation}


The activities of the catalysts are evaluated by the rate constants, which are derived from the steadystate $\mathrm{NO}_{\mathrm{x}}$ conversion measurements. If we assume that the $\mathrm{NH}_{3}-\mathrm{SCR}$ reaction is first order in $\mathrm{NO}$, the rate constant is given by:

$$
k=-\frac{F}{W} \ln (1-X)
$$

where $F$ is the total molar flow rate, $W$ is the mass of the Cu-CHA powder in both tested catalysts, and $X$ is the conversion of NO. The deactivation is expressed as the relative rate constant of a sulfated or regenerated catalyst with respect to the rate constant for the fresh catalyst:

$$
\text { Deactivation }=1-\frac{k}{k_{\text {fresh }}}=1-\frac{A \exp \left(-\frac{E_{a}}{R T}\right)}{A_{\text {fresh }} \exp \left(-\frac{E_{a, \text { fresh }}}{R T}\right)}
$$

Multiplication by 100 then yields the deactivation expressed as a percentage.

\section{Results}

\subsection{Powder experiments}

The general behavior of a $\mathrm{Cu}-\mathrm{CHA}$ catalyst upon exposure to $\mathrm{SO}_{2}$ and regeneration at $550{ }^{\circ} \mathrm{C}$ is illustrated in Figure 1 for the powder catalyst, which shows the measured $\mathrm{NO}_{\mathrm{x}}$ conversions for a fresh catalyst, after exposure to $100 \mathrm{ppm} \mathrm{SO}_{2}$ at $550{ }^{\circ} \mathrm{C}$ (sulfated), and after regeneration at $550{ }^{\circ} \mathrm{C}$ in $\mathrm{SCR}$ gas (regenerated).

The most significant effect of exposure to $\mathrm{SO}_{2}$ is seen in the lower temperature range, up to $300{ }^{\circ} \mathrm{C}$, where $\mathrm{NO}_{\mathrm{x}}$ conversion was significantly inhibited compared to the fresh sample. Above $300{ }^{\circ} \mathrm{C}$, the $\mathrm{NO}_{\mathrm{x}}$ conversion increases rapidly with temperature to slightly above the conversion measured for the fresh catalyst. After regeneration by heating to $550{ }^{\circ} \mathrm{C}$, the conversion above $300{ }^{\circ} \mathrm{C}$ was slightly higher, but close to that of the fresh catalyst. Below $300{ }^{\circ} \mathrm{C}$, the conversion remained slightly below 
that of the fresh catalyst. This shows that exposure to $\mathrm{SO}_{2}$ results mainly in deactivation of the lowtemperature $\left(\mathrm{T}<350{ }^{\circ} \mathrm{C}\right)$ activity of the catalyst, which is consistent with previously reported observations $[5,9,11]$, and regeneration at $550{ }^{\circ} \mathrm{C}$ does not fully restore the activity below $300{ }^{\circ} \mathrm{C}$ entirely.

To investigate if the incomplete regeneration at $550{ }^{\circ} \mathrm{C}$ is due to a too short regeneration time, the regeneration process was monitored by heating the samples at $550{ }^{\circ} \mathrm{C}$ for a total of $12 \mathrm{~h}$ in intervals, where after each interval the activity at $200{ }^{\circ} \mathrm{C}$ was re-evaluated. Figure $2 \mathrm{~A}$ shows the measured activity at $200{ }^{\circ} \mathrm{C}$ obtained in this way, which indicates that a stable activity level is reached at about $75-80 \%$ of the original activity after approximately $4 \mathrm{~h}$ of regeneration. This means that a complete regeneration by heating at $550{ }^{\circ} \mathrm{C}$ seems not possible.

Figure 1 shows that the $\mathrm{NO}_{\mathrm{x}}$ conversion over a catalyst after exposure to $\mathrm{SO}_{2}$ increases slightly with temperature up to $300{ }^{\circ} \mathrm{C}$, followed by a steep increase. To determine whether the slight increase below $300{ }^{\circ} \mathrm{C}$ is due to a normal temperature dependency of a possible residual activity, or to a slow regeneration in this temperature range, we checked the influence of the temperature on activity of a $\mathrm{Cu}$ $\mathrm{CHA}$ catalyst at $200{ }^{\circ} \mathrm{C}$. To do this measurement, a single catalyst sample deactivated by $\mathrm{SO}_{2}$ was sequentially exposed to heating for $2 \mathrm{~h}$ in $5 \% \mathrm{H}_{2} \mathrm{O} / 10 \% \mathrm{O}_{2} / \mathrm{N}_{2}$ at a chosen temperature between 200 and $450{ }^{\circ} \mathrm{C}$ in increasing order, and then cooled down to $200{ }^{\circ} \mathrm{C}$ where the $\mathrm{NO}_{\mathrm{x}}$ conversion was then re-measured. Figure $2 \mathrm{~B}$ shows the rate constant at $200{ }^{\circ} \mathrm{C}$, determined according to Eq. (1) as a function of the heating temperature. The rate constant at $200{ }^{\circ} \mathrm{C}$ does not increase by heating to a temperature of $300{ }^{\circ} \mathrm{C}$ or lower, which clearly indicates that the regeneration of a catalyst exposed to $\mathrm{SO}_{2}$ does not start below $300{ }^{\circ} \mathrm{C}$, and the slight increase in conversion in Figure 1 is therefore due to the temperature dependence of a residual activity. This also means that measured SCR activities after exposure to $\mathrm{SO}_{2}$ are not affected by regeneration if the measurements are done at $300{ }^{\circ} \mathrm{C}$ or lower. 
The observation that the activity after $\mathrm{SO}_{2}$ exposure cannot be completely restored by heating to 550 ${ }^{\circ} \mathrm{C}$ indicates that there are different forms of deactivation. Based on these data, we define these different forms of deactivation as follows: the part of the deactivation that can be restored by $4 \mathrm{~h}$ heating at 550 ${ }^{\circ} \mathrm{C}$ will be referred to as the reversible deactivation, and the remaining part as the irreversible deactivation. The total deactivation is the sum of these two contributions. An activity measured after exposure to $\mathrm{SO}_{\mathrm{x}}$ before regeneration, represents the total deactivation, the irreversible deactivation is found from the activity after regeneration. The reversible deactivation can then be determined as the difference in activity of a $\mathrm{SO}_{\mathrm{x}}$-treated catalyst before and after regeneration. The following expression is used to determine the relative reversible deactivation with respect to the activity of the fresh catalyst:

$$
1-\frac{k_{\text {sulfated }}}{k_{\text {fresh }}}=\text { Reversible deactivation }+\left(1-\frac{k_{\text {irreversible }}}{k_{\text {fresh }}}\right)
$$

\subsection{Monolith experiments}

The effects of $\mathrm{SO}_{3}$, water and $\mathrm{SO}_{x}$ exposure temperature on the catalyst deactivation and regeneration was studied by measurement of $\mathrm{NO}$ conversions over $\mathrm{Cu}-\mathrm{CHA} /$ cordierite monolith samples after exposure to $\mathrm{SO}_{\mathrm{x}}$ at the conditions listed in Table 1, and after subsequent heating at $550{ }^{\circ} \mathrm{C}$. In all these measurements, the deactivation and regeneration followed the same general trend as observed for the $\mathrm{Cu}-\mathrm{CHA}$ powder. Figure 3 shows the measured $\mathrm{NO}_{\mathrm{x}}$ conversion in the range $150-250{ }^{\circ} \mathrm{C}$ after deactivation in wet $\mathrm{SO}_{2}$ without $\mathrm{SO}_{3}$ as an example. Exposure to $\mathrm{SO}_{2}$ leads to a lower $\mathrm{NO}_{x}$ conversion, which is mostly restored by heating at $550^{\circ} \mathrm{C}$. It is noted that all activity measurements shown in Figure 3 are obtained below $300^{\circ} \mathrm{C}$, and are therefore not influenced by regeneration during the measurements.

Due to variations in temperature in the different measurements, a common base for comparison of the measured $\mathrm{NO}_{\mathrm{x}}$ conversions is needed. To this end, Arrhenius plots were constructed; Figure 4 shows 
the Arrhenius plot based on the data in Figure 3, and represents the general observation for all samples (see supporting information). For all conditions, the slopes of the fresh and regenerated states of the catalyst are nearly the same, while the slope of the sulfated state of the catalyst is always smaller. Our interpretation is that the activation energies for the fresh and regenerated catalysts are the same, and the activation energy was determined from the combined data points of the fresh and regenerated states. Consequently, the differences in activity for fresh and regenerated catalysts are translated to differences in the pre-exponential factor. The relative irreversible deactivation then becomes independent of the temperature for the conditions used here. The assignment of irreversible deactivation to changes in the pre-exponential factor implies a mechanism in which deactivation is caused by loss of active sites, without major changes in the chemistry of the reaction.

The situation is different for the sulfated catalysts, which consistently have lower activation energy than the fresh and regenerated catalysts. Table 2 lists the activation energies for the fresh and sulfated samples, and the ratio of the two values. The lower activation energies of the sulfated catalysts also mean that the measured reversible deactivation depends on the temperature of the SCR activity measurement. A change in activation energy cannot be due to a loss of active sites only. Phenomena that could change the activation energy are a change in the chemistry of the $\mathrm{NH}_{3}-\mathrm{SCR}$ reaction and diffusion limitations of the $\mathrm{NH}_{3}-\mathrm{SCR}$ reaction rate in the zeolite crystals after exposure to $\mathrm{SO}_{\mathrm{x}}$. In the limit of strong pore diffusion limitations, the observed activation energy will be half the value of the intrinsic value. In principle, this is an option for the samples treated with $\mathrm{SO}_{2}$ alone. For the samples treated with $\mathrm{SO}_{3}$, the activation energy ratios are lower than 0.5 , which cannot be explained by internal diffusion limitations alone, suggesting that chemical effects are more pronounced in this case.

\subsection{Desorption of $\mathrm{SO}_{2}$}


To determine the amount of sulfur deposited on the catalysts, $\mathrm{SO}_{2}$ concentrations were measured during the regeneration up to and at $550{ }^{\circ} \mathrm{C}$ in SCR-gas, and during heating to $900{ }^{\circ} \mathrm{C}$ in $\mathrm{N}_{2}$ after all activity measurements. The measured $\mathrm{SO}_{2}$ desorption during the regeneration to $550{ }^{\circ} \mathrm{C}$, shown in Figure $5 \mathrm{~A}$, is related to the reversible deactivation. $\mathrm{No}_{\mathrm{SO}_{3}}$ or $\mathrm{H}_{2} \mathrm{SO}_{4}$ desorption was observed during the regeneration. Clearly, the two samples exposed to $\mathrm{SO}_{3}$ at $200{ }^{\circ} \mathrm{C}$ stand out with a substantially higher $\mathrm{SO}_{2}$ desorption around $400{ }^{\circ} \mathrm{C}$. Since the two catalysts exposed to $\mathrm{SO}_{2}$ at $200{ }^{\circ} \mathrm{C}$ did not show a similar high $\mathrm{SO}_{2}$ desorption around $400{ }^{\circ} \mathrm{C}$, the higher desorption of $\mathrm{SO}_{2}$ from the two catalysts exposed to $\mathrm{SO}_{3}$ at $200{ }^{\circ} \mathrm{C}$ must be due to decomposition of $\mathrm{SO}_{3}$ or sulfates $[2,11,12]$. The desorption temperature of $400{ }^{\circ} \mathrm{C}$ is about $200-250{ }^{\circ} \mathrm{C}$ lower than the decomposition temperature of bulk $\mathrm{Cu}$ sulfate [12]. This indicates that only little $\mathrm{Cu}$ sulfate is formed from $\mathrm{SO}_{3}$ at $200{ }^{\circ} \mathrm{C}$, or that the $\mathrm{Cu}$-sulfate species formed this way in the $\mathrm{Cu}-\mathrm{CHA}$ catalysts are less stable than bulk $\mathrm{Cu}$-sulfate.

All other samples, exposed to $\mathrm{SO}_{2}$ at $200{ }^{\circ} \mathrm{C}$ or $\mathrm{SO}_{2}+\mathrm{SO}_{3}$ at $550{ }^{\circ} \mathrm{C}$, show similar $\mathrm{SO}_{2}$ desorption peaks at approx. $300{ }^{\circ} \mathrm{C}$ and $475{ }^{\circ} \mathrm{C}$. This means that exposure to $\mathrm{SO}_{3}$ at $550{ }^{\circ} \mathrm{C}$ essentially results in similar sulfur species as exposure to $\mathrm{SO}_{2}$ at 200 or $550{ }^{\circ} \mathrm{C}$, and the influence of water is limited. The observed desorption temperatures are consistent with decomposition of ammonium sulfate [5] and sulfuric acid $[12,15]$. Ammonium sulfates can possibly have been formed by the exposure of the sulfated samples to $\mathrm{NH}_{3}$ during the SCR activity measurement directly after the $\mathrm{SO}_{x}$ exposure [10], which would imply a reaction of the adsorbed sulfur species and ammonia.

Figure $5 \mathrm{~B}$ shows the desorption of $\mathrm{SO}_{2}$ during heating in $\mathrm{N}_{2}$ to $900{ }^{\circ} \mathrm{C}$ after $\mathrm{SO}_{\mathrm{x}}$ exposure and regeneration, which represents the sulfur species associated with irreversible deactivation. The catalysts exposed to $\mathrm{SO}_{3}$ at $200{ }^{\circ} \mathrm{C}$ show again the largest amount of $\mathrm{SO}_{2}$. The desorption peak is centered around $675{ }^{\circ} \mathrm{C}$ for all samples, indicating that the same species is formed in all catalysts, but in different amounts, dependent on the conditions for $\mathrm{SO}_{2}$ exposure. The temperature of $675{ }^{\circ} \mathrm{C}$ is consistent with the irreversible deactivation being related to formation of $\mathrm{Cu}$-sulfate [12]. 
From integration of the curves in Figure 5, the amounts of sulfur in the sulfated and regenerated catalysts can be estimated, and we highlight the differences in sulfur content between the samples exposed to $\mathrm{SO}_{3}$ at $200{ }^{\circ} \mathrm{C}$ and the other samples. The quality of the measured $\mathrm{SO}_{2}$ concentrations during regeneration is poor, but the differences between the samples exposed to $\mathrm{SO}_{3}$ at $200{ }^{\circ} \mathrm{C}$ and the other ones are quite clear. We also note that no $\mathrm{SO}_{3}$ was detected during the temperature programmed desorption, and no sulfur was found in an ICP-OES analysis of the catalysts after heating to $900{ }^{\circ} \mathrm{C}$. This means that the amounts of sulfur detected in the desorption measurements accounts for all sulfur present in the catalysts.

Table 3 lists the $\mathrm{SO}_{2} / \mathrm{Cu}$ ratios related to the reversible and irreversible deactivation as derived from integration of the $\mathrm{SO}_{2}$ desorption curves and the $\mathrm{Cu}$ content in the zeolite. The $\mathrm{SO}_{2} / \mathrm{Cu}$ ratios of all samples are below 1, which indicates that not all $\mathrm{Cu}$ has reacted with $\mathrm{SO}_{\mathrm{x}}$, which would be required for complete formation of $\mathrm{Cu}$-sulfate. The $\mathrm{SO}_{2} / \mathrm{Cu}$ ratio after exposure to $\mathrm{SO}_{3}$ at $200{ }^{\circ} \mathrm{C}$ in dry gas is 0.58 , and 0.90 in the presence of water, and $70-80 \%$ of this amount is released during regeneration at 550 ${ }^{\circ} \mathrm{C}$. In all other cases, the $\mathrm{SO}_{2} / \mathrm{Cu}$ ratio is 0.1-0.2.

\subsection{Influence of $\mathrm{SO}_{2} / \mathrm{SO}_{3}$, water and temperature on deactivation}

Having established the general trends in performance and sulfur content after sulfation, and regeneration of the $\mathrm{Cu}-\mathrm{CHA}$ catalyst, we now turn our attention to the effects of temperature of $\mathrm{SO}_{\mathrm{x}}$ exposure, and the presence of water or $\mathrm{SO}_{3}$. Figure $6 \mathrm{~A}$ and $\mathrm{B}$ show the reversible and irreversible deactivation for the samples exposed to $\mathrm{SO}_{2}$ only and $\mathrm{SO}_{2}+\mathrm{SO}_{3}$. The reversible deactivation was

derived from interpolation of the activity data to $180{ }^{\circ} \mathrm{C}$, using the Arrhenius plots given in Figure 2 and supporting information. The deactivation is given as a percentage according to Eq. (2). 
The effect of $\mathrm{SO}_{3}$ on deactivation is most noticeable with $\mathrm{SO}_{\mathrm{x}}$ exposure at $200{ }^{\circ} \mathrm{C}$, leading to significantly stronger deactivation, compared to exposure to $\mathrm{SO}_{2}$ alone both in dry and wet feed gases. At $550{ }^{\circ} \mathrm{C}$, the there is no apparent influence of $\mathrm{SO}_{3}$ in the feed gas. This shows that the specific deactivation by $\mathrm{SO}_{3}$ is most important in the lower temperature range, and that the effect of $\mathrm{SO}_{3}$ on deactivation is related to the pronounced decomposition of $\mathrm{SO}_{3}$ or sulfate at $400{ }^{\circ} \mathrm{C}$, as shown in Figure $5 \mathrm{~A}$.

The presence of $\mathrm{H}_{2} \mathrm{O}$ during $\mathrm{SO}_{\mathrm{x}}$ exposure always leads to higher irreversible deactivation than the corresponding dry $\mathrm{SO}_{\mathrm{x}}$ exposure condition, but appears to have no consistent influence on reversible deactivation. With respect to the impact of temperature, irreversible deactivation is always greater in the samples exposed at $200{ }^{\circ} \mathrm{C}$ than the corresponding sample exposed at $550{ }^{\circ} \mathrm{C}$, whereas no consistent impact of temperature is observed on reversible deactivation. The general picture that emerges is that the presence of $\mathrm{SO}_{3}$ and water at $200{ }^{\circ} \mathrm{C}$ has a stronger effect on the deactivation than at $550{ }^{\circ} \mathrm{C}$, in particular on irreversible deactivation.

\section{Discussion}

The similar activation energies in the SCR reaction for the fresh and regenerated states of the catalysts indicates that irreversible deactivation is the result of having fewer active sites available, and the desorption temperature for $\mathrm{SO}_{2}$ from the regenerated catalysts points to the formation of $\mathrm{Cu}$-sulfate. If $\mathrm{Cu}$-sulfate formation is the cause of deactivation, a 1:1 correlation should exist between the irreversible deactivation and the sulfur content. Figure 7 shows the measured irreversible deactivation as a function of the $\mathrm{SO}_{2} / \mathrm{Cu}$ ratio, derived from the corresponding $\mathrm{SO}_{2}$ desorption measurements in Figure $5 \mathrm{~B}$, together with the line for the 1:1 correlation. The measured irreversible deactivation actually follows the 1:1 correlation with the sulfur content fairly well, corroborating the idea that $\mathrm{Cu}$-sulfate formation is responsible for the irreversible deactivation [2,5-13]. 
A way to envision the irreversible deactivation by formation of a $\mathrm{Cu}$-sulfate species is a reaction of $\mathrm{SO}_{3}$ with a $\mathrm{Cu}$-ion balanced by a single $\mathrm{Al}$ and a hydroxide ligand $(\mathrm{Z}-\mathrm{Cu}-\mathrm{OH})$, as in reaction scheme (4).

$$
\mathrm{Z}-\mathrm{Cu}-\mathrm{OH}+\mathrm{SO}_{3} \rightarrow \mathrm{Z}-\mathrm{Cu}-\mathrm{HSO}_{4}
$$

In this case, the hydroxide ligand provides the oxygen required for formation of sulfate. $\mathrm{A} \mathrm{Cu}^{2+}$ ion balanced by two $\mathrm{Al}$-sites $\left(\mathrm{Z}_{2}-\mathrm{Cu}\right)$ does not have the hydroxide ligand, but this does not necessarily mean that these $\mathrm{Cu}$-species are incapable of sulfate formation. In the presence of water, $\mathrm{a} \mathrm{Z}_{2}-\mathrm{Cu}$ can react to a $\mathrm{Z}-\mathrm{Cu}-\mathrm{OH}$ and a $\mathrm{Br} \varnothing n s t e d$ acid site [14], and the $\mathrm{Z}-\mathrm{Cu}-\mathrm{OH}$ can then react further with $\mathrm{SO}_{3}$ according to reaction scheme (4). The overall reaction then becomes:

$$
\mathrm{Z}_{2}-\mathrm{Cu}+\mathrm{SO}_{3}+\mathrm{H}_{2} \mathrm{O} \rightarrow \mathrm{Z}-\mathrm{Cu}-\mathrm{HSO}_{4}+\mathrm{Z}-\mathrm{H}
$$

A similar scenario is a reaction with sulfuric acid $\left(\mathrm{H}_{2} \mathrm{SO}_{4}\right)$ and a $\mathrm{Z}_{2}-\mathrm{Cu}$ site, where the sulfuric acid is formed by reaction of $\mathrm{SO}_{3}$ and water. Either way, the presence of water would facilitate formation of $\mathrm{Cu}$-sulfate as this leads to a higher amount of $\mathrm{Z}-\mathrm{Cu}-\mathrm{OH}$-sites compared to dry conditions. The suggested reaction schemes then offer an explanation for the increase in irreversible deactivation in the presence of water. This means that a model that describes the irreversible deactivation by formation of $\mathrm{Cu}$-sulfate is also consistent with the observed effects of the presence of water.

A comparison of measured deactivation and the sulfur content for the sulfated catalysts reveals a different behavior for reversible deactivation. Figure 8 shows the total deactivation of the sulfated catalysts as a function of their total $\mathrm{SO}_{2} / \mathrm{Cu}$ ratios. Clearly, there is no consistent 1:1 dependence of the total deactivation on $\mathrm{SO}_{2} / \mathrm{Cu}$ ratio, with only small $\mathrm{SO}_{2} / \mathrm{Cu}$ ratios, between 10-20\%, leading to degrees of deactivation as high as $60-80 \%$. This indicates that the loss of activity in this case is not caused by a direct interaction of a single sulfur atom with a single $\mathrm{Cu}$ ion, as the measured deactivation is $5-10$ times higher than expected from a 1:1 correlation. 
The lower activation energies of the sulfated catalysts might be due to formation of internal diffusion limitations induced by $\mathrm{SO}_{\mathrm{x}}$ deactivation, which can play a role in the deactivation process. In case of increased diffusion limitations, the effectiveness factor should become lower in addition to the loss of sites, resulting in an overall deactivation that is higher than the fraction of $\mathrm{Cu}$ sites in contact with sulfur. This agrees, at least qualitatively, with the results shown in Figure 8. To evaluate a possible effect of diffusion limitations, the effectiveness factor, $\eta$, was calculated for the fresh catalyst, assuming spherical zeolite crystals and first order reaction kinetics in NO. For the calculations, the crystal radius was set to $0.5 \mu \mathrm{m}$, which is a reasonable value given that the crystal size of the zeolite is on the order of $1 \mu \mathrm{m}$. A further description of the calculation of the effectiveness factor is given in supporting information. Figure 9 shows the effectiveness factor as a function of the effective diffusion coefficient, $D_{\text {eff, at }} 180{ }^{\circ} \mathrm{C}$. By extrapolation of experimentally determined values for effective diffusion coefficients for $\mathrm{NH}_{3}$ in a $\mathrm{Cu}-\mathrm{CHA}$ catalyst, using the corresponding activation energy [16], we find a diffusion coefficient of $1.2 \cdot 10^{-9} \mathrm{~m}^{2} / \mathrm{s}$. Using this diffusion coefficient, Figure 9 shows that the effectiveness factor for the fresh catalyst is close to 1 . This implies that no internal diffusion limitation is expected in the crystals of the fresh catalyst. Because the activation energy of the regenerated catalysts is the same as for the fresh, diffusion effects can be excluded for the irreversible deactivation as well.

If the reduction of the effective activation energy to half the intrinsic value would be due to diffusion limitations, the effectiveness factor should decrease to be lower than 0.8 , where there is a linear relationship between $\log (\eta)$ and $\log \left(D_{\text {eff }}\right)$ resulting in a straight line in Figure 9. According to Figure 9, to obtain an effectiveness factor of 0.8 , a decrease of the diffusion coefficient by about a factor of 100 would be required. This would mean that the small amount of sulfur, corresponding to less than $20 \%$ coverage of the $\mathrm{Cu}$-sites, reduces the diffusion coefficient by a factor of 100 . This seems unlikely, also 
taking into account that a similar sulfur content in the regenerated catalysts does not affect the activation energy and diffusion.

Alternatively, pore-blocking by possible formation of ammonium sulfates may be considered as a cause for the reversible deactivation behavior. We note that the sulfated catalysts are exposed to $\mathrm{SO}_{2}$ without ammonia present, and therefore, the resulting sulfur species is most likely bound to the $\mathrm{Cu}$-ions [13]. If ammonium sulfate is formed by subsequent exposure to ammonia, this implies that the ammonium sulfate species is also located close to the $\mathrm{Cu}$-ions. The $\mathrm{SO}_{2} / \mathrm{Cu}$ ratios in the sulfated catalysts is about 0.15 (except in those exposed to $\mathrm{SO}_{3}$ at $200{ }^{\circ} \mathrm{C}$ ), which is similar to the $\mathrm{SO}_{2} / \mathrm{Cu}$ ratio in some of the regenerated catalysts, where it was argued that there is no diffusion limitation. Therefore, it seems unlikely that the presence of these fairly small amounts of ammonium sulfate effectively block access to most of the zeolite. At present, the question of how the limited amount of sulfur can have such a strong impact on the reversible deactivation remains unanswered.

Having ruled out diffusion as a cause for reversible deactivation, the lower activation energy must then be related to changes in the chemistry. An interesting concept is $\mathrm{Cu}$ being able to form a mobile diamine species at SCR conditions. These mobile $\mathrm{Cu}$-diamine species are important for the low-temperature activity of $\mathrm{Cu}-\mathrm{CHA}$ catalysts [17-20]. Possibly, the reversible deactivation by sulfur oxide species inhibits the formation of these mobile $\mathrm{Cu}$ diamine complexes, thereby lowering the mobility of $\mathrm{Cu}$ and the $\mathrm{NH}_{3}-\mathrm{SCR}$ activity, which might lead to the observed high degree of reversible deactivation with low amounts of sulfur.

Finally, our data clearly show that exposure to $\mathrm{SO}_{\mathrm{x}}$ at lower temperatures result in the largest deactivation. However, most of the catalytic activity can be regained by heating to $550{ }^{\circ} \mathrm{C}$, even after exposure to $\mathrm{SO}_{3}$ at $200{ }^{\circ} \mathrm{C}$. This is an interesting result from an application point of view, since it 
indicates that regeneration strategies based on heating to easily obtainable temperatures in exhaust systems are a feasible solution to handle deactivation of $\mathrm{Cu}$-zeolites by $\mathrm{SO}_{2}$ and $\mathrm{SO}_{3}[10,13]$.

\section{Conclusion}

To evaluate different aspects of sulfur poisoning of $\mathrm{NH}_{3}-\mathrm{SCR}$ activity, $\mathrm{Cu}-\mathrm{CHA}$ catalysts were exposed to $\mathrm{SO}_{2}$ or a 70:30 mixture of $\mathrm{SO}_{2}$ and $\mathrm{SO}_{3}$, in dry or moist conditions and at low and high temperature, and were evaluated before and after regeneration at $550{ }^{\circ} \mathrm{C}$. After $\mathrm{SO}_{\mathrm{x}}$ exposure, a high degree of deactivation is observed at temperatures below $300{ }^{\circ} \mathrm{C}$. A major part of this deactivation is reversible by heating to $550{ }^{\circ} \mathrm{C}$ for $4 \mathrm{~h}$, while a smaller, but appreciable, level of irreversible deactivation remains.

The mechanisms behind the reversible and irreversible deactivation differs. Irreversible deactivation is proportional to the sulfur content in the catalyst and consistent with the formation of a $\mathrm{Cu}$-sulfate species. Reversible deactivation is not proportional to the sulfur content, and shows a strong deactivation already at low $\mathrm{SO}_{2} / \mathrm{Cu}$ ratios.

The presence of water always increases irreversible deactivation, but has no apparent effect on reversible deactivation. Exposure to $\mathrm{SO}_{\mathrm{x}}$ at $200{ }^{\circ} \mathrm{C}$, always leads to a higher level of irreversible deactivation compared to exposure at $550{ }^{\circ} \mathrm{C}$. The presence of $\mathrm{SO}_{3}$ at $200{ }^{\circ} \mathrm{C}$ leads to significantly stronger deactivation; at $550{ }^{\circ} \mathrm{C}$, deactivation by $\mathrm{SO}_{3}$ is not significantly different from that by $\mathrm{SO}_{2}$. Regeneration of $\mathrm{Cu}-\mathrm{CHA}$ exposed to $\mathrm{SO}_{3}$ at $200{ }^{\circ} \mathrm{C}$ is accompanied by a decomposition of $\mathrm{SO}_{3}$ and release of $\mathrm{SO}_{2}$ around $400{ }^{\circ} \mathrm{C}$.

In all experiments, the reversible deactivation accounts for most of the total deactivation, which makes regeneration by heating to $550{ }^{\circ} \mathrm{C}$, an easily obtainable temperature in exhaust systems, a realistic approach to deal with deactivation by $\mathrm{SO}_{\mathrm{x}}$. 


\section{Acknowledgements}

PSH gratefully acknowledges support from Innovation Fund Denmark [grant number 5139-0023B]. YJ gratefully acknowledges support from Cummins Inc. 


\section{References}

[1] I. Nova, E. Tronconi, Urea-SCR Technology for deNOx After Treatment of Diesel Exhausts, 1st ed., Springer, 2014.

[2] Y. Cheng, C. Lambert, D.H. Kim, J.H. Kwak, S.J. Cho, C.H.F. Peden, Catal. Today 151 (2010) 266.

[3] T. Fushun, Z. Ke, Y. Fang, Y. Lili, X.U. Bolian, Q.I.U. Jinheng, F.A.N. Yining, Chinese J. Catal. 33 (2012) 933.

[4] Y. Cheng, C. Montreuil, G. Cavataio, C. Lambert, SAE Int. J. Fuels Lubr. 1 (2015) 471.

[5] L. Zhang, D. Wang, Y. Liu, K. Kamasamudram, J. Li, W. Epling, Appl. Catal. B 156-157 (2014) 371.

[6] K. Wijayanti, S. Andonova, A. Kumar, J. Li, K. Kamasamudram, N.W. Currier, A. Yezerets, L. Olsson, Appl. Catal. B 166-167 (2015) 568.

[7] K. Wijayanti, K. Leistner, S. Chand, A. Kumar, K. Kamasamudram, N.W. Currier, A. Yezerets, L. Olsson, Catal. Sci. Technol. 6 (2016) 2565.

[8] J. Luo, D. Wang, A. Kumar, J. Li, K. Kamasamudram, N. Currier, Catal. Today (2015).

[9] Y. Jangjou, M. Ali, Q. Chang, D. Wang, J. Li, A. Kumar, W.S. Epling, Catal. Sci. Technol. 6 (2016) 2679.

[10] Y. Jangjou, D. Wang, A. Kumar, J. Li, W.S. Epling, ACS Catal. 6 (2016) 6612.

[11] A. Kumar, M.A. Smith, K. Kamasamudram, N.W. Currier, H. An, A. Yezerets, Catal. Today 231 (2014) 75.

[12] W. Su, Z. Li, Y. Zhang, C. Meng, J. Li, Catal. Sci. Technol. 7 (2017) 1523.

[13] A. Kumar, M.A. Smith, K. Kamasamudram, N.W. Currier, A. Yezerets, Catal. Today 267 (2016) 10.

[14] C. Paolucci, A.A. Parekh, I. Khurana, J.R. Di Iorio, H. Li, J.D.A. Caballero, A.J. Shih, T. Anggara, W.N. Delgass, J.T. Miller, F.H. Ribeiro, R. Gounder, W.F. Schneider, J. Am. Chem. Soc. 138 (2016) 6028.

[15] H. Li, A. Shih, A. Kumar, I. Khurana, C. Paolucci, J.T. Miller, A. Yezerets, R. Gounder, F.H. Ribeiro, W.F. Schneider, in:, 2017.

[16] A.J. O’Malley, I. Hitchcock, M. Sarwar, I.P. Silverwood, S. Hindocha, C.R.A. Catlow, A.P.E. York, P.J. Collier, Phys. Chem. Chem. Phys. 18 (2016) 17159.

[17] F. Gao, D. Mei, Y. Wang, J. Szanyi, C.H.F. Peden, J. Am. Chem. Soc. 139 (2017) 4935.

[18] F. Giordanino, E. Borfecchia, K.A. Lomachenko, A. Lazzarini, G. Agostini, E. Gallo, A. V 
Soldatov, P. Beato, S. Bordiga, C. Lamberti, J. Phys. Chem. Lett. 5 (2014) 1552.

[19] S. Shwan, M. Skoglundh, L.F. Lundegaard, R.R. Tiruvalam, T.V.W. Janssens, A. Carlsson, P.N.R. Vennestrøm, ACS Catal. 5 (2015) 16.

[20] C. Paolucci, I. Khurana, A.A. Parekh, S. Li, A.J. Shih, H. Li, J.R. Di Iorio, J.D. AlbarracinCaballero, A. Yezerets, J.T. Miller, W.N. Delgass, F.H. Ribeiro, W.F. Schneider, R. Gounder, Science 357 (2017) 898. 


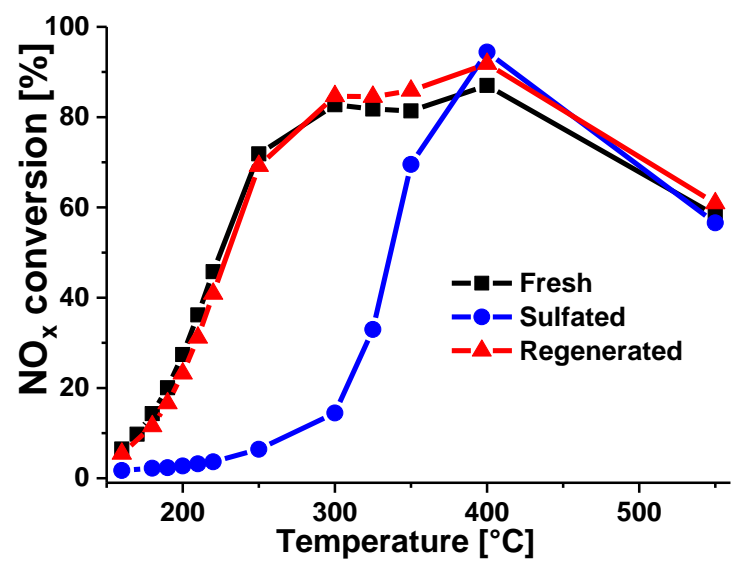

Figure $1-N O_{x}$ conversion as function of temperature of a $\mathrm{Cu}$-CHA catalyst ( $\mathrm{Si} / \mathrm{Al}=14.7, \mathrm{Cu} / \mathrm{Al}=0.5$, and $2.8 \mathrm{wt} \% \mathrm{Cu}$ ) in fresh, sulfated and regenerated state. $\mathrm{SCR}$ conditions: $500 \mathrm{ppmv} \mathrm{NO}, 530 \mathrm{ppmv} \mathrm{NH}_{3}, 10 \% \mathrm{O}_{2}, 5 \% \mathrm{H}_{2} \mathrm{O}, \mathrm{N}_{2}$ balance to $0.225 \mathrm{NL} / \mathrm{min}$ on $5.0 \mathrm{mg}$ catalyst in reactor with an inner diameter of $2 \mathrm{~mm}$. SO $\mathrm{S}_{x}$ exposure conditions: $100 \mathrm{ppmv} \mathrm{SO}_{2}, 16 \% \mathrm{O}_{2}, \mathrm{~N}_{2}$ balance to $0.2 \mathrm{NL} / \mathrm{min}$ for $16 \mathrm{~h}$ at 550 ${ }^{\circ} \mathrm{C}$. Regeneration conditions: $4.6 \mathrm{~h}$ at $550{ }^{\circ} \mathrm{C}$ in SCR-gas.
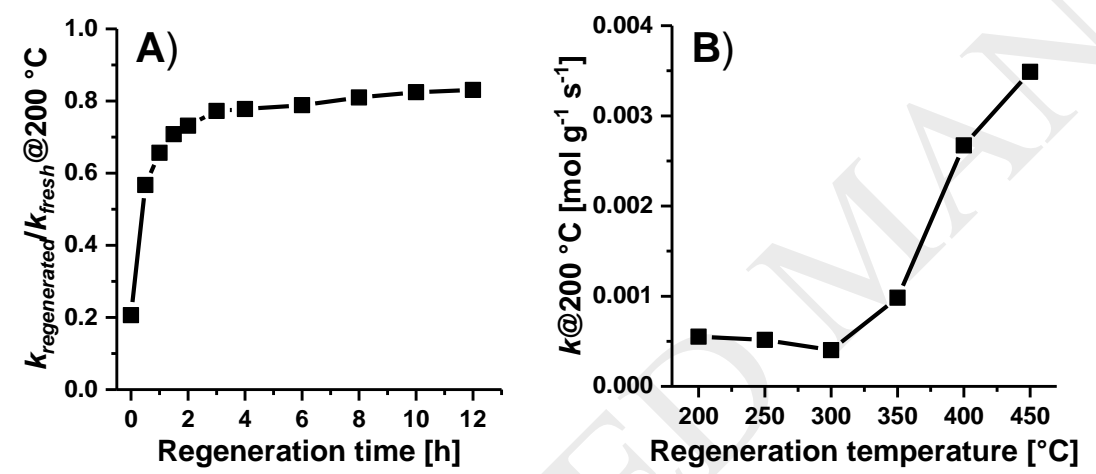

Figure $2-\mathrm{Cu}$-CHA catalyst $(\mathrm{Si} / \mathrm{Al}=14.7, \mathrm{Cu} / \mathrm{Al}=0.5$, and $2.8 \mathrm{wt} \% \mathrm{Cu}) \mathrm{A})$ Relative $\mathrm{NH}_{3}$-SCR activity plotted as function of regeneration time. $\mathrm{NO}_{x}$ conversions measured on $5.0 \mathrm{mg}$ catalyst at $200^{\circ} \mathrm{C}$ on fresh catalyst, after $\mathrm{SO}_{2}$ exposure, and after every regeneration step at $550{ }^{\circ} \mathrm{C}$ in SCR-gas. $\mathrm{SO}_{x}$ exposure conditions: $40 \mathrm{ppmv} \mathrm{SO}_{2}, 10 \% \mathrm{O}_{2}, 5 \% \mathrm{H}_{2} \mathrm{O}, \mathrm{N}_{2}$ balance to $0.225 \mathrm{NL} / \mathrm{min}$ for 1 h at $\left.550{ }^{\circ} \mathrm{C} . \mathrm{B}\right) \mathrm{NH}_{3}$ SCR activity at $200^{\circ} \mathrm{C}$ plotted as function of regeneration temperature (2 hat each regeneration temperature). NO $O_{x}$ conversions measured on $5.0 \mathrm{mg}$ catalyst at $200{ }^{\circ} \mathrm{C}$ on fresh catalyst, after $\mathrm{SO}_{2}$ exposure, and after every regeneration step at increasing temperature in SCRgas. $\mathrm{SO}_{2}$ exposure conditions: $100 \mathrm{ppmv} \mathrm{SO}_{2}, 16 \% \mathrm{O}_{2}, \mathrm{~N}_{2}$ balance to $0.2 \mathrm{NL} / \mathrm{min}$ for $16 \mathrm{~h}$ at $550{ }^{\circ} \mathrm{C}$. 


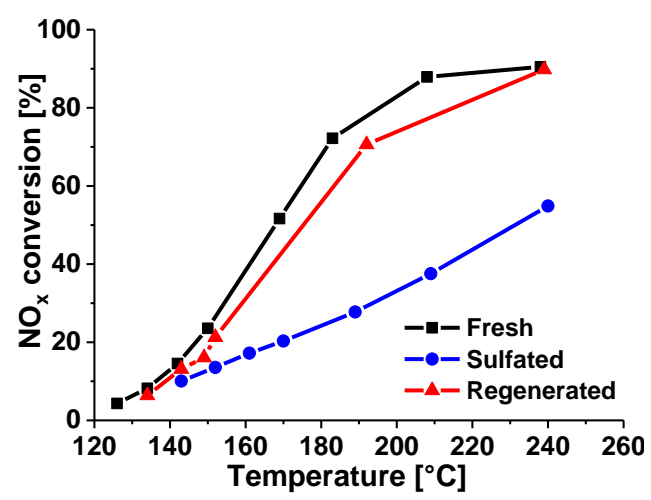

Figure 3 - $\mathrm{NO}_{x}$ conversion as function of temperature of a $\mathrm{Cu}$-CHA/cordierite catalyst $(\mathrm{Cu}-\mathrm{CHA}$ : $\mathrm{Si} / \mathrm{Al}=16.6,2.5 \mathrm{wt} \% \mathrm{Cu})$ in fresh, sulfated and regenerated state. SCR conditions: 500 ppmv $\mathrm{NO}, 530 \mathrm{ppmv} \mathrm{NH}_{3}, 10 \% \mathrm{O}_{2}, 5 \% \mathrm{H}_{2} \mathrm{O}$, $\mathrm{N}_{2}$ balance to $8.0 \mathrm{NL} / \mathrm{min}$ on $20 \times 27$ mm cylindrical monolith catalyst in reactor with an inner diameter of $25.4 \mathrm{~mm}$. SO $\mathrm{S}_{x}$ exposure conditions: $100 \mathrm{ppmv} \mathrm{SO}_{2}, 10 \% \mathrm{O}_{2}, 5 \%$ $\mathrm{H}_{2} \mathrm{O}$, $\mathrm{N}_{2}$ balance to $8.0 \mathrm{NL} / \mathrm{min}$ for 3 h at $200{ }^{\circ} \mathrm{C}$. Regeneration conditions: $4 \mathrm{~h}$ at $550{ }^{\circ} \mathrm{C}$ in $\mathrm{SCR}$-gas.

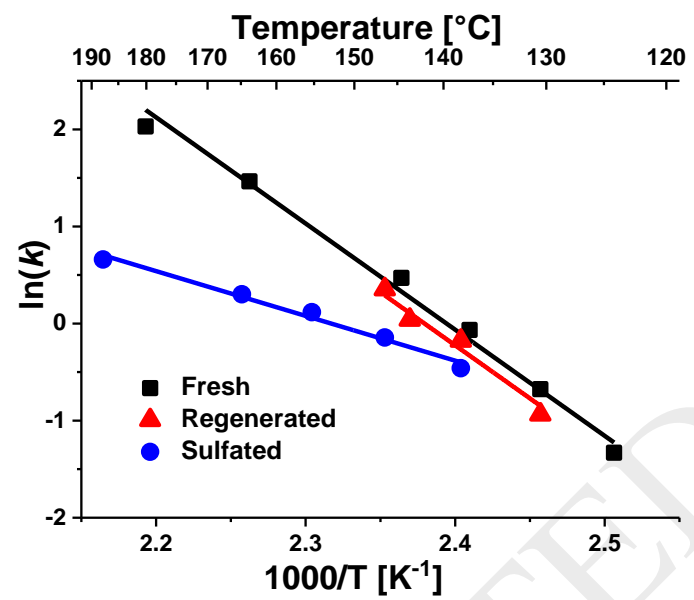

Figure 4 -Arrhenius plot of a $\mathrm{Cu}$-CHA/cordierite catalyst (Cu-CHA: Si/Al=16.6, $2.5 \mathrm{wt} \% \mathrm{Cu}$ ) in fresh, sulfated and regenerated state. SO $\mathrm{O}_{x}$ exposure conditions: 100 ppmv $\mathrm{SO}_{2}, 10 \% \mathrm{O}_{2}, 5 \% \mathrm{H}_{2} \mathrm{O}, \mathrm{N}_{2}$ balance to $8.0 \mathrm{NL} /$ min for $3 \mathrm{~h}$ at $200{ }^{\circ} \mathrm{C}$. Regeneration conditions: $4 \mathrm{~h}$ at $550^{\circ} \mathrm{C}$ in SCR-gas. 


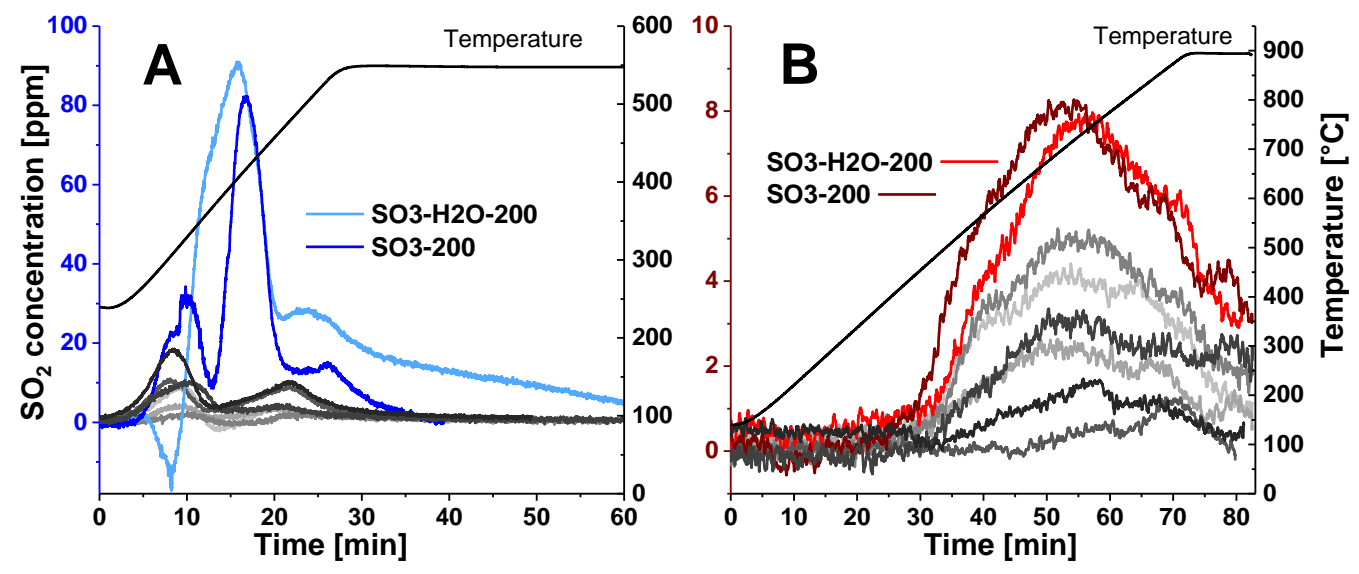

Figure $5-\mathrm{SO}_{2}$ desorption spectra for sulfated $\mathrm{Cu}$-CHA/cordierite catalysts, $\mathrm{A}$ ) during heating to $550{ }^{\circ} \mathrm{C}$ at $10^{\circ} \mathrm{C} / \mathrm{min}$ in $\mathrm{SCR}$-gas with a total flowrate of $8.0 \mathrm{NL} / \mathrm{min}$, after sulfation, $\boldsymbol{B}$ ) during heating to $900{ }^{\circ} \mathrm{C}$ at $10^{\circ} \mathrm{C} / \mathrm{min}$ in $8.0 \mathrm{NL} / \mathrm{min} \mathrm{N} 2$, after sulfation and regeneration for 4 h at $550^{\circ} \mathrm{C}$. Curve-smoothing has been applied on the curves in $\boldsymbol{B}$, using an adjecent-averaging method. In both $\boldsymbol{A}$ and $\boldsymbol{B}$, legends are only provided for the catalysts exposed to $\mathrm{SO}_{3}$ at $200{ }^{\circ} \mathrm{C}$. Plots containing legends for all catalysts can be found in supporting information.

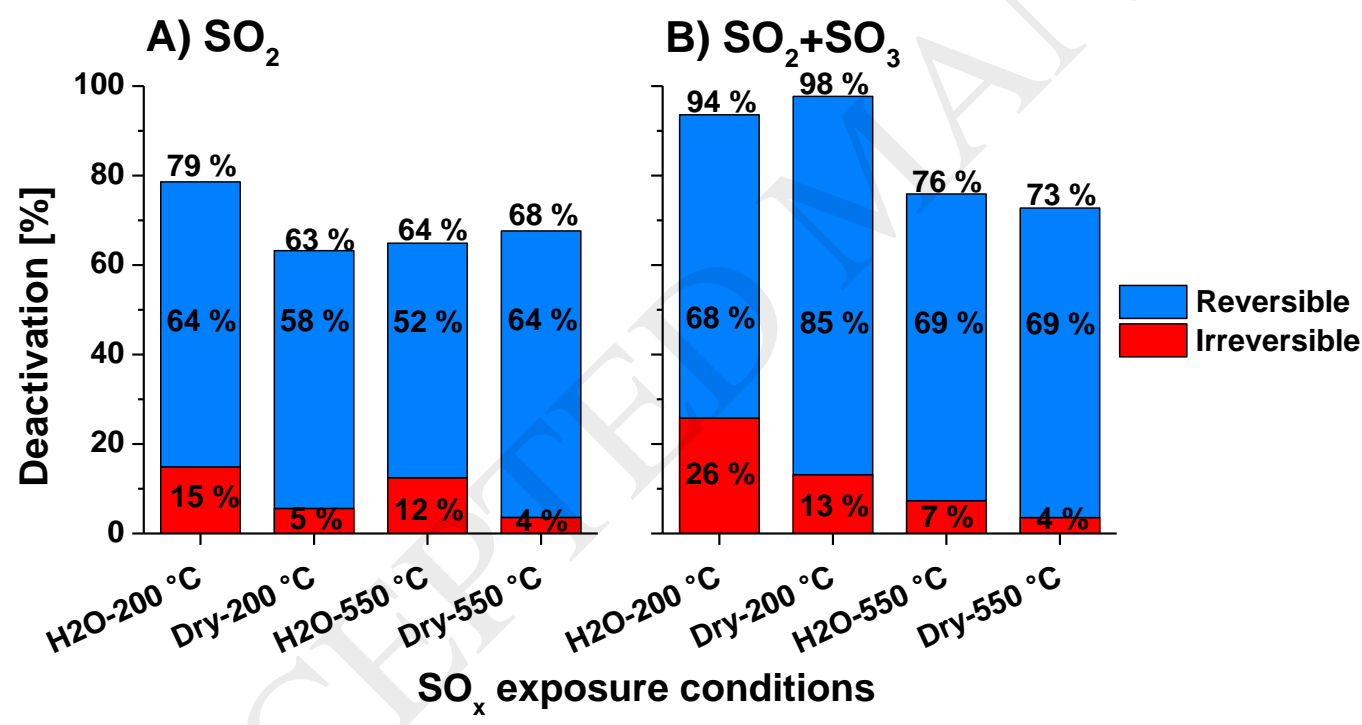

Figure 6 - The reversible deactivation (green bars), irreversible deactivation (red bars) and total deactivation (sum of red and green bars) plotted for each $\mathrm{SO}_{x}$ exposure condition of the $\mathrm{Cu}$-CHA/cordierite catalysts. $\mathrm{A}$ ) samples exposed to $\left.100 \mathrm{ppmv}^{\mathrm{SO}} \mathrm{O}_{2}, \mathrm{~B}\right) \mathrm{samples}$ exposed to $70 \mathrm{ppmv}^{\mathrm{SO}} \mathrm{O}_{2}$ and $30 \mathrm{ppmv}^{\mathrm{SO}} \mathrm{O}_{3}$ 


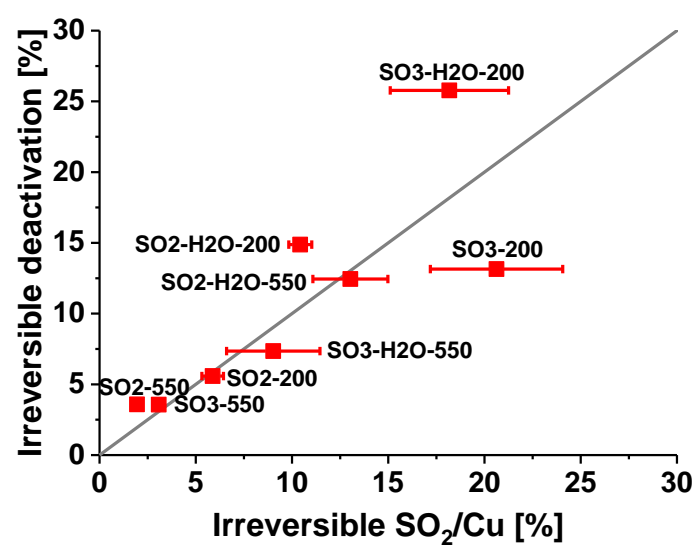

Figure 7 - The irreversible deactivation for the $\mathrm{Cu}$-CHA/cordierite catalysts, determined after $\mathrm{SO}_{x}$ exposure and regeneration for $4 \mathrm{~h}$ at $550{ }^{\circ} \mathrm{C}$, plotted as function of the $\mathrm{SO}_{2} / \mathrm{Cu}$ ratio of the irreversible $\mathrm{S}$-species.

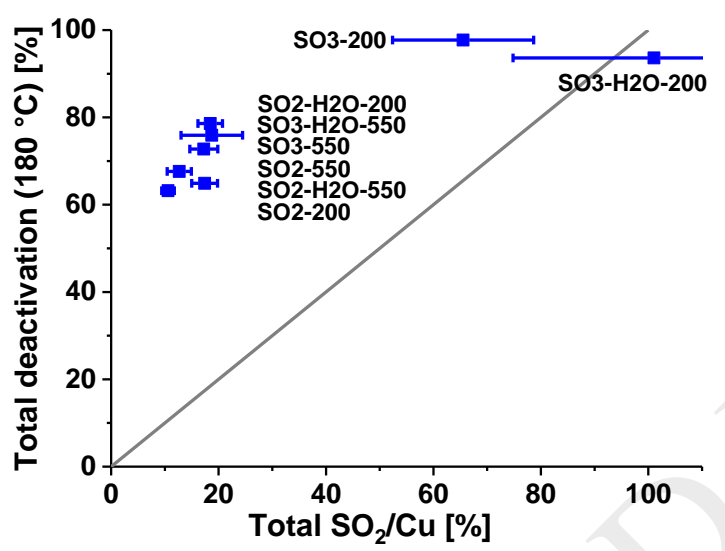

Figure 8 - The total deactivation for the $\mathrm{Cu}$-CHA/cordierite catalysts, determined after $\mathrm{SO}_{x}$ exposure, plotted as function of the $\mathrm{SO} / \mathrm{Cu}$ ratio of the total $S$-species. 


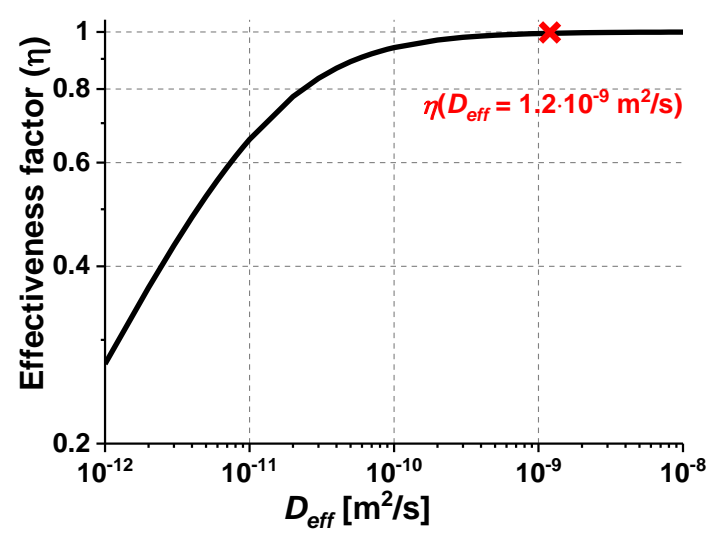

Figure 9 - Double logarithmic plot of the internal effectiveness factor in the zeolite crystals, $\eta$, at $180{ }^{\circ} \mathrm{C}$, as a function of the effective diffusion coefficient, $D_{\text {eff. }} \eta$ based on experimental values for $D_{\text {eff }}$ of $\mathrm{NH}_{3}$ in a $\mathrm{Cu}$-CHA catalyst in the range $0-100{ }^{\circ} \mathrm{C}$, is marked, which indicates that the reaction in the fresh catalyst is not limited by diffusion of reactants. 
Table 1 - Assigned sample names according to variations in $\mathrm{SO}_{x}$ exposure conditions.

\begin{tabular}{|c|c|c|}
\hline $\mathrm{SO}_{\mathrm{x}}$ exposure conditions & $100 \mathrm{ppm} \mathrm{SO}_{2}$ & $70 \mathrm{ppm} \mathrm{SO}_{2}+30 \mathrm{ppm} \mathrm{SO}$ \\
\hline $\begin{array}{lll}5 & \% & \mathrm{H}_{2} \mathrm{O} \\
\mathrm{T}=200{ }^{\circ} \mathrm{C} & & \end{array}$ & $\mathrm{SO} 2-\mathrm{H} 2 \mathrm{O}-200$ & $\mathrm{SO} 3-\mathrm{H} 2 \mathrm{O}-200$ \\
\hline $\begin{array}{l}\text { Dry } \\
\mathrm{T}=200^{\circ} \mathrm{C}\end{array}$ & SO2-200 & SO3-200 \\
\hline $\begin{array}{l}5 \% \mathrm{H}_{2} \mathrm{O} \\
\mathrm{T}=550{ }^{\circ} \mathrm{C}\end{array}$ & $\mathrm{SO} 2-\mathrm{H} 2 \mathrm{O}-550$ & SO3-H2O-550 \\
\hline $\begin{array}{l}\text { Dry } \\
\mathrm{T}=550{ }^{\circ} \mathrm{C}\end{array}$ & SO2-550 & SO3-550 \\
\hline
\end{tabular}

Table 2 -Activation energies of fresh $\left(E_{a, \text { fresh }}\right)$ and sulfated $\left(E_{a, \text { sulfated }}\right)$ states of the tested $\mathrm{Cu}$-CHA/cordierite catalysts, and the ratios of $E_{a, \text { sulfated }} / E_{a, \text { fresh }}$

\begin{tabular}{|l|l|l|l|}
\hline Sample & $E_{a, f r e s h}\left[\mathrm{~kJ} \mathrm{~mol}^{-1}\right]$ & $E_{a \text {,sulfated }}\left[\mathrm{kJ} \mathrm{mol}^{-1}\right]$ & $\begin{array}{l}E_{a, \text { sulfated }} / E_{a, f r e s h} \\
(\text { min-max })\end{array}$ \\
\hline SO2-H2O-200 & $91 \pm 8$ & $38 \pm 5$ & $0.33-0.53$ \\
\hline SO2-200 & $99 \pm 3$ & $53 \pm 2$ & $0.50-0.58$ \\
\hline SO2-H2O-550 & $90 \pm 7$ & $53 \pm 1$ & $0.54-0.65$ \\
\hline SO2-550 & $59 \pm 3$ & $30 \pm 5$ & $0.41-0.63$ \\
\hline SO3-H2O-200 & $80 \pm 26$ & $15 \pm 2$ & $0.12-0.32$ \\
\hline SO3-200 & $115 \pm 16$ & $39 \pm 4$ & $0.27-0.45$ \\
\hline SO3-H2O-550 & $97 \pm 4$ & $39 \pm 1$ & $0.38-0.43$ \\
\hline SO3-550 & $76 \pm 5$ & $31 \pm 1$ & $0.36-0.45$ \\
\hline
\end{tabular}

Table 3 - The reversible, irreversible and total $\mathrm{SO}_{2} / \mathrm{Cu}$ ratios of all $\mathrm{Cu}$-CHA/cordierite catalyst samples.

\begin{tabular}{|l|l|l|l|}
\hline Sample & $\begin{array}{l}\text { Reversible } \\
\mathrm{SO}_{2} / \mathrm{Cu}\end{array}$ & $\begin{array}{l}\text { Irreversible } \\
\mathrm{SO}_{2} / \mathrm{Cu}\end{array}$ & Total $\mathrm{SO}_{2} / \mathrm{Cu}$ \\
\hline $\mathrm{SO} 2-\mathrm{H} 2 \mathrm{O}-200$ & 0.07 & 0.09 & 0.16 \\
\hline $\mathrm{SO} 2-200$ & 0.04 & 0.05 & 0.09 \\
\hline $\mathrm{SO} 2-\mathrm{H} 2 \mathrm{O}-550$ & 0.04 & 0.12 & 0.16 \\
\hline $\mathrm{SO} 2-550$ & 0.10 & 0.02 & 0.12 \\
\hline $\mathrm{SO} 3-\mathrm{H} 2 \mathrm{O}-200$ & 0.74 & 0.16 & 0.90 \\
\hline $\mathrm{SO} 3-200$ & 0.40 & 0.18 & 0.58 \\
\hline SO3-H2O-550 & 0.09 & 0.08 & 0.17 \\
\hline SO3-550 & 0.13 & 0.03 & 0.16 \\
\hline
\end{tabular}

